\title{
Scale of Illegal Killing and Trade Associated with Indian Pangolin (Manis crassicaudata) in Pakistan
}

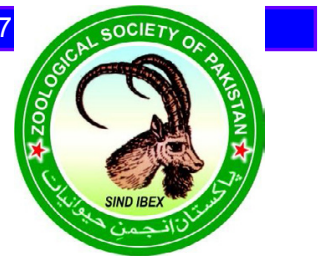

\author{
Muhammad Waseem ${ }^{1}$, Ahmed Raza ${ }^{1}$, Hamera Aisha ${ }^{1}$, Muhammad Naeem Awan', \\ Tariq Ahmad ${ }^{2}$, Rabia Nazir ${ }^{2}$ and Tariq Mahmood ${ }^{2, *}$ \\ ${ }^{1}$ WWF Pakistan, Islamabad office, Pakistan \\ ${ }^{2}$ Department of Wildlife Management, PMAS-Arid Agriculture University, Rawalpindi \\ 46300, Pakistan
}

\begin{abstract}
A B S T R A C T
The Indian pangolin (Manis crassicaudata) found in Pakistan is threatened by the rampant trade of the species, and has been listed as endangered since 2014 and also included in Appendix-I of CITES. The IUCN estimates indicate a decrease of $\geq 50 \%$ in the global Indian pangolin population over the next 21 years, highlighting the need for protecting the species against illegal trade. In the current study, we investigated the scale of its poaching and illegal trade in the country. Results revealed that poachers use spotlight and tracking techniques (42\% respondents). Summer is the best season for poaching the pangolins (44\% respondents). Forest is best preferred habitat of pangolin (54\% respondents) and pangolins selling and buying points are located outside the villages (63\% respondents). Nomads, semisettled people at different locations in the Potohar Plateau are actively involved in pangolin trade and poaching. Approximately 275 pangolins were poached at 46 different locations during 2013-2018, with the highest number of killings recorded from Chakwal District (131 pangolins at 14 sites). The pangolin dealers operating in major cities of Pakistan (Rawalpindi, Lahore and Karachi) prefer pangolin scales. A total of 239 shops and street vendors were trading many wildlife species including CITES listed species in the market illegally in addition to pangolins. Karachi and Lahore had highest number of shops dealing with illegal wildlife trade.
\end{abstract}

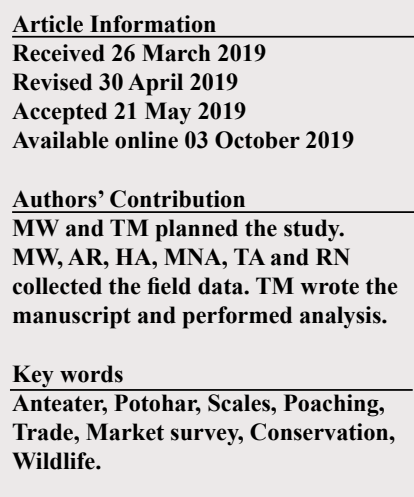

\section{INTRODUCTION}

$\mathrm{P}$ angolins or scaly anteaters are unique being the world's only truly scaly mammals, but are in dire need of urgent conservation action due to their illegal trade for scales and meat demand. Occurring in Africa and Asia, all eight species of pangolins have been exploited for food and traditional medicines through history. This continues today, despite protective measures in most countries in which they occur. The main threat to pangolins today, both in Asia and increasingly in Africa, is hunting and poaching for illegal international trade. This typically involves live pangolins, and their meat and scales, which are primarily destined to East Asia, most conspicuously China and Vietnam. The pangolin populations in Asia have been declining rapidly in recent decades, driven by international trade (Challender et al., 2014). As populations in China have been depleted ( $\mathrm{Wu}$ et al., 2004) the source of pangolins has shifted to Southeast Asia (Newton et al., 2008) and South Asia (Mahmood et al., 2012), and facilitated by increasing economic ties with African

\footnotetext{
Corresponding author: tariqjanjua75@uaar.edu.pk 0030-9923/2020/0069-0001 \$ 9.00/0

Copyright 2020 Zoological Society of Pakistan
}

nations, to Africa as well (Challender and Hywood, 2012). As a result, pangolin populations in Asia are in precipitous decline, and have been extirpated from vast areas. Worryingly, inter-continental trade in African pangolin parts to Asian markets is now taking place (IUCN, 2014).

Pangolins (Order Pholidota; Manis spp.) are insectivorous mammals confined to the Afro-tropical and Indo-Malayan regions, with 8 extant species recognized (Corbet and Hill, 1992, Gaubert and Antunes, 2005). All 4 Asiatic pangolin species are classified as "Endangered" (IUCN, 2018) and appear in Appendix-I of the Convention on International Trade in Endangered Species of Wild Fauna and Flora (CITES, 2016).

Indian pangolin (Manis crassicaudata) is locally distributed in Pakistan, occurring in small populations in all four provinces of the country (Roberts, 1997). The Potohar Plateau is also one of its important habitats where the species was previously estimated to be widely distributed (Mahmood et al., 2017) ranging over approximately $89 \%$ of the Potohar Plateau. The species is also reported from some districts of the Azad Jammu and Kashmir part of Pakistan, occurring in Kotli, Bhimber and Mirpur districts. The poaching and illegal killing of Indian pangolin in Potohar Plateau have been previously reported by Mahmood et al. (2012) and Mahmood et al. (2019). 
Poaching and illegal killing of pangolins is still occurring in the Potohar Plateau at the alarming scale.

The Indian pangolin has been included as Endangered on the IUCN Red List of Threatened Species. These listings are based on evident (Wu et al., 2004; Wu and Ma, 2007) and suspected, rapidly declining populations (Challender et al., 2014a; Baillie et al., 2014). Despite these measures, pangolins in Pakistan continue to be exploited for local consumptive uses and are frequently found in illegal trade, both domestically and internationally (e.g. Baillie et al., 2014), but information on the extent of trade is limited and inconsistent. Previous studies (e.g. Mahmood et al., 2012) have highlighted the illegal trade and killing of Indian pangolins in Pakistan and the smuggling of their scales into China via Hong Kong and perhaps Singapore. In April 2012 information was reported (GACC, 2012) on a seizure in China of $25.4 \mathrm{~kg}$ of pangolin scales that were apparently sourced from Pakistan, where illegal smuggling is facilitated by weak law enforcement (Mehmood et al., 2019). This is partly because these species are widely distributed geographically, making it difficult to quantify hunting and poaching activities, localities and associated trends, and because illegal trade in pangolins is characteristically clandestine. The aim of the current study was to collect information on recent poaching and illegal killing, trade and use of pangolin body parts by traditional medicine practitioners in Pakistan.

\section{MATERIALS AND METHODS}

\section{Study area}

The first component of the study (questionnaire survey about illegal killing of pangolin) was conducted in the Potohar Plateau in northeast Pakistan during July, 2018. The study area comprised four districts (Attock, Chakwal, Jhelum, Rawalpindi), and also some parts of the Azad Jammu \& Kashmir (Mirpur, Bhimbar, Kotli). The Plateau is at $330-1000 \mathrm{~m}$ altitude and the climate is semiarid to humid, with mean annual rainfall of 380-510 $\mathrm{mm}$. It has a total area of 1.82 million ha out of which only 0.61 million ha are cultivated; the remaining land is under gullies, scrub forest and rangeland which is being used for rough grazing (Munawar et al., 2018). The mean maximum temperature in summer is $45^{\circ} \mathrm{C}$, dropping to below freezing during winter (Encyclopaedia Britannica, 2016). Of the 178 protected areas in Pakistan eight occur in the Potohar Plateau: five National Parks (Kala Chitta, Chinji, Margalla Hills, Murree-Kahuta-Kotli Sattiyan and Khairi Murat), two Wildlife Sanctuaries (Chumbi Surla and Islamabad) and one Game Reserve (Domeli-Diljaba). Similarly, the second part of the study was conducted in metropolitan cities of Pakistan, including Peshawar, Rawalpindi, Lahore and Muzafarabad to investigate illegal trade of pangolin during market surveys.

\section{Community survey}

Questionnaire based surveys were conducted in the study area focusing on local hunters, farmers, shopkeepers, shepherds and school children. During the survey period a total of 250 questionnaires were filled out from the study area including 25 questionnaires from each district. Survey questions included hunters living in the proximity of the study area and were interviewed about their knowledge of pangolin ecology, historic and contemporary pangolin hunting practices, and the dynamics of the trade in pangolins. Interviewees were selected according to their availability and willingness to participate in an informal interview. Since it is illegal to hunt in protected areas or to trade a pangolin without a permit, the issues discussed were extremely sensitive and complete random sampling within the hunter population was not possible. This selection method was feasible and realistic surrogate given the restrictions of time and the sensitive nature of the study topic. Interviews varied in content, length and interviewee attitude and knowledge, and there were often an almost unlimited number of possible responses to a given question.

\section{Animal markets survey}

The purpose of this survey was to collect information on Indian pangolin and also other wildlife species being sold or traded illegally in local markets, their price and common forms in which they are available, to determine the trends and demands of local markets and trafficking route of the animals. To serve the purpose of the survey, four categories of markets and locations in these cities were defined including firstly, wild animals / bird markets and pet shops etc. that dealt with live animal species, secondly, street vendors which sell a number of products made from wild animal derivatives in the open market and roam in interior parts of a city, thirdly, local herbalists (Hakeem) which too sell medicines extracted from wild animal derivatives and are located in suburban parts of a cities, and fourthly, souvenir shops.

\section{Survey methodology}

Given the criminal nature of this business, undercover surveys were conducted with a team of three persons visited markets and other suggested locations as potential buyers. Guidelines for survey teams were developed to ensure a consistent methodology and approach to collect information, while ensuring safety protocols. The questionnaire used carried inquiries to help quantify the volume of traded animals and sale, trends of pangolin trade, price of both live animals and their derivatives, purpose of their use, availability status as well as identification 
of main group/groups involved in the illegal trade. The length of each survey was spread out over the period of three days.

\section{RESULTS}

\section{Local hunters identified}

These results are based on feedback from 250 respondents ( 50 from each of the five Districts studied). The respondents also included local hunters who had directly or indirectly sighted, trapped, killed and or sold the pangolins in any way. The potential hunters in the study area involved in illegal killing/poaching of pangolin included maximum numbers of hunters in Chakwal District ( $\mathrm{n}=21$, at 15 locations), followed by Rawalpindi ( $\mathrm{n}=18$, at 9 locations), Attock ( $\mathrm{n}=16$, at 07 locations), Jhelum ( $\mathrm{n}=12$, at 8 locations) and Mirpur $(\mathrm{n}=9$, at 8 locations) (Fig. 1).

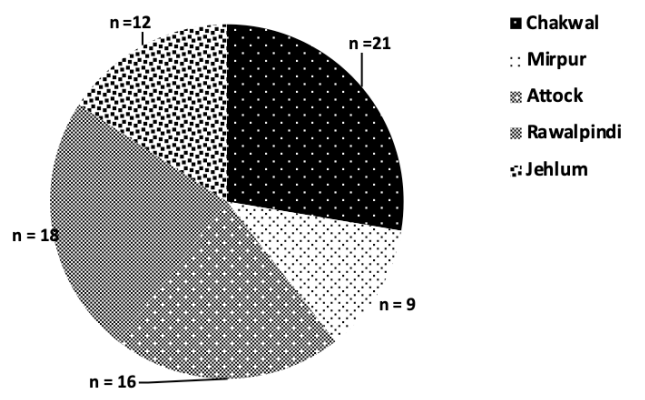

Fig. 1. Records of local hunters in the five districts of the study area, involved in illegal trapping/killing of Indian pangolin ( $\mathrm{n}$ is the numbers of hunters).

Capture techniques, preferred season, location and time

Semi structured questionnaire survey conducted in different villages of Potohar Plateau \& Mirpur, AJ\&K, comprised of different questions asked from the respondents including trapping techniques, preferred season for hunting/poaching, preferred time for hunting and selling/ buying point (Fig. 2). About 38\% of the respondents viewed that hunter dogs could be used for trapping the pangolins, while other $42 \%$ thought that spotlighting and tracking are the major techniques for pangolin trapping (Fig. 2). Similarly, 44\% of the respondents were of the view that preferred time for trapping pangolins is late summer when there is groundnut vegetation in the fields, while 54\% respondents replied that capturing/trapping pangolins was occurring from forested area and $63 \%$ of the respondents indicated preferred night time for trapping purpose as the pangolin comes out from their burrows at night for food. Similarly, regarding specific point/location for selling and buying of the pangolins, $63 \%$ thought that there is no specific point in the village from where one can easily sell or buy pangolins. Majority of the animal stuff was being shifted/transported outside the village (Fig. 2). Villagers had seen the pangolin inside and outside of the village in different years but the respondents indicated that the pangolin population was dramatically decreasing within the study area for the last 3-4 years. According to the respondents, excessive killing/trapping of pangolin by hunters, the habitat loss and alteration in the way of land use pattern were the main causes of pangolin disappearance from these localities.

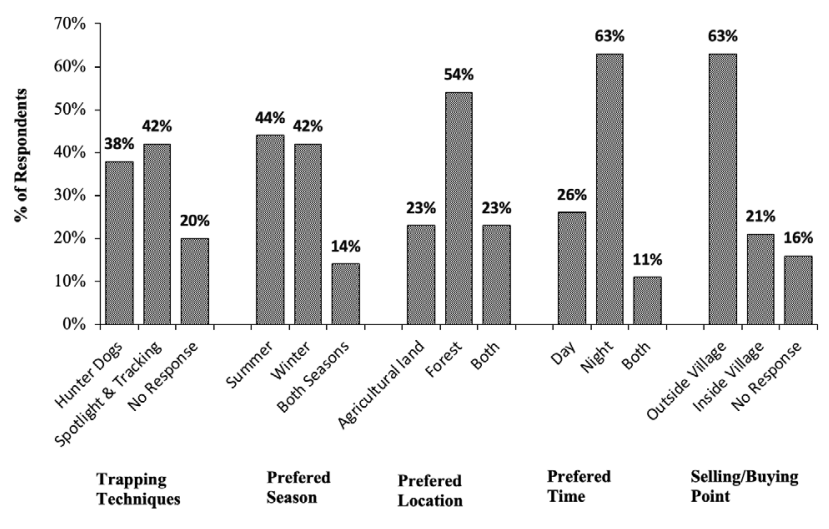

Fig. 2. Trapping technique, hunting season, habitat type, hunting time, and location of illegal killing of Indian pangolin in the study area (total numbers of respondents in each district were $\mathrm{n}=50$ ).

\section{Pangolins killed}

Multiple evidence of the illegal killing of Indian Pangolins collected from the study area revealed killing of the species from 46 different locations across all four districts of Potohar region and Mirpur district of AJ\&K during 2013-2018 (Table I). Maximum poaching and killing occurred in Chakwal District $(n=160)$, followed by in Attock district $(n=120)$. Overall, a total of 380 pangolins were recorded to be illegally killed between 2013-2018 (Fig. 3).

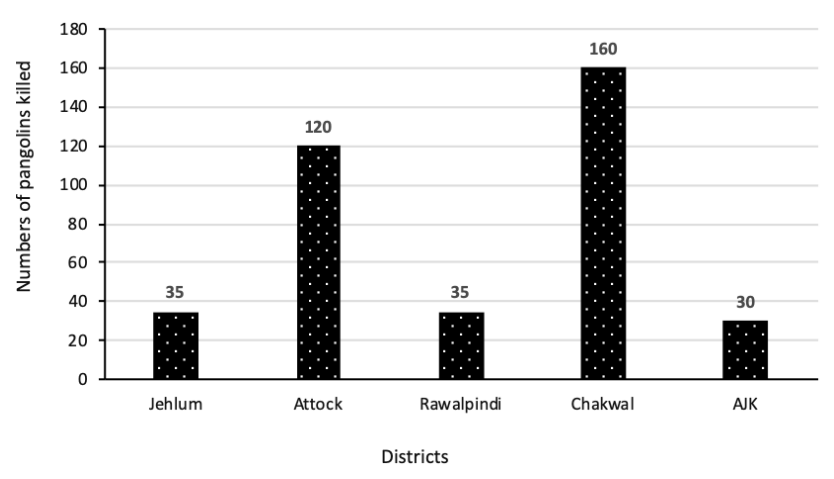

Fig. 3. Numbers of pangolins (Manis crassicaudata) killed/trapped and their illegal trade during last five years (2013-2018). 
Table I.- Records of illegal capture and killing of the Indian Pangolin Manis crassicaudata in the four districts of Potohar Plateau and Mirpur (AJK) during 2013-2018.

\begin{tabular}{|c|c|c|}
\hline Site name & Record date & Details of capture/kill/trap \\
\hline \multicolumn{3}{|c|}{ District Jhelum (08 localities) } \\
\hline Baghan & 8-Jul-18 & Trapped 1 Pangolin \\
\hline Potha & 8-Jul-18 & 1 Pangolin killed \\
\hline Potha & 8-Jul-18 & 5 Pangolins killed and sold $1 \mathrm{~kg}$ scale of the animal in 2017 \\
\hline Potha & 8-Jul-18 & 2 Pangolin killed in each year by professional hunter \\
\hline Akhwanabad & 8-Jul-18 & 2 Pangolins killed in 2014 \\
\hline Potha & 8-Jul-18 & 10 Pangolins killed in each year \\
\hline Mehsian & 7-Jul-18 & 1 Pangolin killed in 2015 \\
\hline Budhan mera & 7-Jul-18 & 8 Pangolins killed 3-4 years ago \\
\hline \multicolumn{3}{|l|}{ Attock (07 localities) } \\
\hline $\begin{array}{l}\text { New Airport Dhok } \\
\text { Miacha }\end{array}$ & 17-Jul-18 & 12 pangolins killed 3-4 years ago and sold to the Chinese \\
\hline Morat & 17-Jul-18 & 1 Pangolin killed in 2014 \\
\hline Jamhat & 18-Jul-18 & $\begin{array}{l}\text { Professional hunter (Noor Muhammad) killed } 16 \text { pangolins and sold out } \\
\text { to dealer from Lahore in } 2016 \text {. }\end{array}$ \\
\hline Malhuwali & 18-Jul-18 & 2 Pangolins killed 5 years ago and sold out to the dealer from Dhulian \\
\hline Malhuwali & 18-Jul-18 & 15 Pangolins killed in Dec,2017 and sold out to the dealer \\
\hline Pindigaib(Nomads) & 18-Jul-18 & 16 pangolins killed every year and sold out to dealer from Lahore \\
\hline Chak Chudrian & 18-Jul-18 & 2 Pangolins killed 3-4 years ago \\
\hline \multicolumn{3}{|c|}{ Rawalpindi (09 localities) } \\
\hline Sehr & 11-Jul-18 & 3 Pangolins killed and sold out to dealer from Rawalpindi \\
\hline Sehr & 11-Jul-18 & 2 Pangolins captured and sold out in Rawalpindi city \\
\hline Kalyal & 11-Jul-18 & 3 Pangolins killed and sold out \\
\hline Do beran & 11-Jul-18 & 1 Pangolin captured \\
\hline Dumhali & 11-Jul-18 & 10 Pangolins captured and sold out to a buyer from Chakwal \\
\hline Bandhal & 11-Jul-18 & 4 Pangolins trapped and sold out to a dealer \\
\hline Sehr & 11-Jul-18 & 2 Pangolins captured during 2014-15 and sold out to a dealer from Lahore. \\
\hline Soora & 10-Jul-18 & 1 Pangolins captured and sold out \\
\hline Pind Jathan & 10-Jul-18 & 1 Pangolins trapped and sold out to dealer from Bahria Town Rawalpindi \\
\hline \multicolumn{3}{|c|}{ Chakwal (14 localities) } \\
\hline Dher mund & 12-Jul-18 & 5 Pangolins killed and sold out to the dealer (Lahore) \\
\hline Kherpur (Kallar kahar) & 19-Jul-18 & 40 Pangolins killed and sold out to dealers (Rwp, Lahore) \\
\hline Kherpur (Kallar kahar) & 19-Jul-18 & $1 \mathrm{~kg}$ scale of Pangolin sell in RS. 10,000 \\
\hline Dhrabi & 12-Jul-18 & 1 Pangolin trapped from forest and sold out during the year 2016-17 \\
\hline Bharpur & 12-Jul-18 & 15 Pangolins killed in each year and sold out to the local and non-local dealers \\
\hline Bharpur & 12-Jul-18 & $\begin{array}{l}\text { Trapped } 1 \text { Pangolin with the help of hunter dogs and sold out to the local } \\
\text { dealer }\end{array}$ \\
\hline Kherpur (Kalar kahar) & 19-Jul-18 & 1 Pangolin trapped from forest and sold out to buyer in expensive price \\
\hline
\end{tabular}




\begin{tabular}{|c|c|c|}
\hline Site name & Record date & Details of capture/kill/trap \\
\hline Dher mund & 12-Jul-18 & 20 Pangolins trapped from their farm lands. \\
\hline Dhrabi & 12-Jul-18 & 3 Pangolins trapped and killed them and sold the scales of pangolin \\
\hline \multirow[t]{2}{*}{ Dher mund } & 12-Jul-18 & $\begin{array}{l}26 \text { Pangolins killed during the year 2013-18 and sold out to the Chinese } \\
\text { company }\end{array}$ \\
\hline & & (Islamabad) through local dealers in expensive price \\
\hline Dhrabi & 12-Jul-18 & 4 Pangolins killed during the year 2015-16 from their farm lands and forests \\
\hline Bharpur & 12-Jul-18 & 8 Pangolins captured and sold out to the dealers (Rwp,isb,lahore) \\
\hline Kariyala & 13-Jul-18 & $\begin{array}{l}3 \text { Pangolins captured from forests and sold out to Chinese through local dealer } \\
\text { during the year 2014-15 }\end{array}$ \\
\hline Kariyala & & 3 Pangolins killed and sold out to the buyer in multiple cities (Rwp.,Lahore) \\
\hline \multicolumn{3}{|c|}{ Mirpur (AJK) (08 localities) } \\
\hline Pir Gali & 4-Jul-18 & Trapped 4 pangolins and scales of animal during the year 2003-04 \\
\hline Kaladhab & 5-Jul-18 & 1 pangolin captured in 2017 and sold out outside the village (Rwp) \\
\hline \multirow[t]{2}{*}{ Islamgarh } & 5-Jul-18 & $\begin{array}{l}\text { Trapped } 8 \text { pangolins during the year } 2000-2001 \text { and sold out in Rawalpindi \& } \\
\text { Lahore. }\end{array}$ \\
\hline & & Scales of pangolins also sold to the dealer in Lahore in RS 2000/per kg \\
\hline Islamgarh & 6-Jul-18 & 1 Pangolin trapped \\
\hline Ghumma & 6-Jul-18 & 1 Pangolin trapped two years ago and sold out in Lahore through dealer \\
\hline Kasghuma & 6-Jul-18 & 4 Pangolins each year and sell in Lahore and Jhelum \\
\hline Jandala & 6-Jul-18 & $\begin{array}{l}2 \text { pangolins trapped and sold out on buyers from Lahore during the year 2016- } \\
17\end{array}$ \\
\hline Potha & 6-Jul-18 & 2 pangolins trapped and sold out on a party from Lahore \\
\hline
\end{tabular}

Table II.- Detail of illegal hunting/ possession of Pangolins from the Potohar Plateau and AJ\&K part of Pakistan during 2011-2017.

\begin{tabular}{|c|c|c|c|c|c|}
\hline $\begin{array}{l}\text { Sr. } \\
\text { No. }\end{array}$ & District & $\begin{array}{l}\text { No. of person } \\
\text { arrested }\end{array}$ & $\begin{array}{l}\text { Crime (Illegal hunt, illegal possession, } \\
\text { illegal trade) }\end{array}$ & $\begin{array}{l}\text { No. of animals } \\
\text { recovered }\end{array}$ & $\begin{array}{l}\text { Penalties } \\
\text { charged (Rs.) }\end{array}$ \\
\hline 1 & ${ }^{1}$ Chakwal & 26 & Illegal hunting and possession of Pangolins & 34 & $10,000 /-60,000 /-$ \\
\hline 2 & ${ }^{2}$ Rawalpindi & 5 & illegal possession of Pangolins & 2 & $10,000 /-20,000 /-$ \\
\hline 3 & ${ }^{3}$ Jhelum & 4 & - & - & $35,000 /-$ \\
\hline 4 & ${ }^{4} \mathrm{AJ} \& \mathrm{~K}$ & 94 & illegal hunting Wildlife & - & $10,000 /-$ \\
\hline Total & & 129 & & 36 & $145,000 /-$ \\
\hline
\end{tabular}

Source of information:

${ }^{1}$ Punjab Wildlife and Parks Department, District Chakwal, Govt. of the Punjab.

${ }^{2}$ Punjab Wildlife and Parks Department, District Rawalpindi, Govt. of the Punjab.

${ }^{3}$ Punjab Wildlife and Parks Department, District Jhelum, Govt. of the Punjab.

${ }^{4}$ Wildlife and Fisheries Department, Govt. of Azad Jammu and Kashmir

\section{Trade route}

The information collected from respondents revealed that local hunters from inside and outside the village trap and kill the pangolin when sighted or dig out it from its burrow using different techniques including smoking the animals out and flushing them out with water; pitfall traps and hunting with dogs are also reported to be used to hunt and trap pangolins. The captured pangolins are then killed by putting them in boiling water tank or with the use of a club to render them unconscious. The 
scales are then typically removed by skinning the dead animal or peeling off the scales. In addition, there is also involvement of nomads of the study area (people without fixed habitation regularly move to and from the same areas, including nomadic hunter-gatherers, pastoral nomads owning livestock, and tinker or trader nomads) in the capturing and selling of pangolin on large scale (Fig. 4). These nomads are in direct contact with dealers (middle man) from Lahore, Rawalpindi and Karachi cities. They have large network of individuals including locals and hunters inside and outside of the village who trap the pangolins and then hand over to the nomadic hunters on fixed price that may be PKR 18000-2000. Different dealers from Lahore, Rawalpindi and Karachi including Chinese personals from Islamabad, collect the scales as well as live animal (depending upon the feasibility) from trader nomads in large quantity. Pangolin scales were reported to be sold for Rs 1000-2000/kg while live animal were sold for Rs. 50,000-60,000. These scales as well as dead pangolins are illegally exported to other countries like China, Hong Kong and Vietnam. Despite the apparent decline in the volume of scales seized, this illegal trade is nevertheless persistent and can be attributed to high demand from different countries including China, primarily, where scales are used in traditional Chinese medicines (TCM), and to increasing prices, which are driving the illegal trade in pangolins from South Asia, as well as from Africa and Southeast Asia.

\section{Poachers and hunters arrested}

Information collected also revealed that provincial and district Wildlife Departments arrested a total of 129 people from the study area between 2011-2017 from different districts and recovered a total of 36 pangolins that were illegally captured and were in their possession (Table II). The arrested people were fined @ Rs. 30,000 -35,000 along with 6 months of imprisonment for wildlife trade offence. The number of recorded seizures associated with Potohar region and AJ\&K between 2011 and 2018 confirms the country role as an important hub in the international pangolin trade.

\section{Undercover market survey}

A survey of a total of 239 shops including animal, birds and pet shops, local Hakeem, street vendors and Pansari from five metropolitan cities viz. Rawalpindi, Peshawar, Lahore, Karachi and Muzaffarabad, revealed their involvement in the illegal trade of wildlife species, although some markets catered to legal pet trade in birds species. We identified few dealers in "Thokar Niaz Baig", in Lahore city, who are involved in large scale trafficking of Pangolin meat and scales within the city and outside the city as well (Fig. 5). These dealers sell the pangolin scales at varying prices ranging between Rs.17000-18000/ $\mathrm{kg}$ to the Chinese nationals visiting Pakistan and residing in DHA Lahore. Similarly, they also provide live pangolins to the buyers on demand. We could not find the scales and meat of pangolins at herbalist's shops, street vendors and local Hakeems. These shop owners were primarily dealing with other wildlife species including lizards, seashells etc.

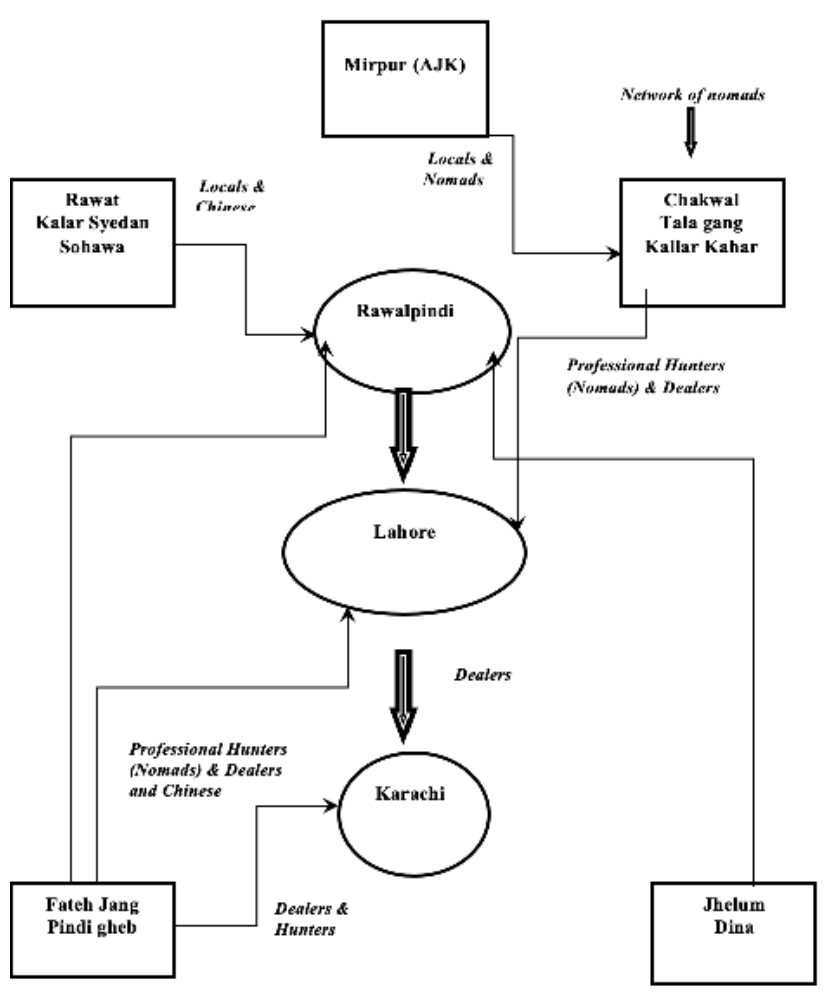

Fig. 4. Schematic diagrams showing the trade route of Indian Pangolins in Pakistan.
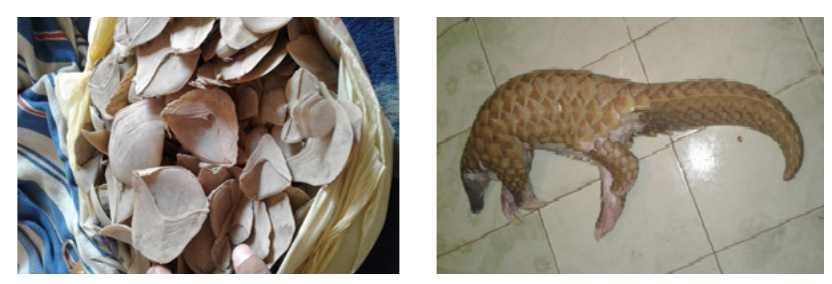

Fig. 5. An Indian Pangolin (Manis crassicaudata) and its scales that were recovered from Lahore during the market survey in the year 2018 .

\section{DISCUSSION}

In Pakistan, Indian Pangolin is protected under the Islamabad Wildlife (Protection, Preservation, Conservation, and Management) Ordinance, 1979 and 
Khyber Pakthunkhawa Province Wildlife (Protection, Preservation, Conservation, and Management) Act, 1975. It is included in the third schedule of Punjab Wildlife Act, 1974 (Amendment 2007). According to third schedule, it is protected throughout the year. The species is also included in the Appendix-I of the CITES since 2016, according to which any international trade of the species and its products (scales) is prohibited legally. Despite legislative protection provided to Indian pangolin in the country and also internationally, illegal exploitation and trade in pangolins and their body parts continue to occur in Pakistan, which is having a seemingly deleterious effect on pangolin populations.

The illegal killing and trade of Indian pangolin has got a history in the country. It was previously reported by Mahmood et al. (2012) that massive illegal hunting and killing of the species was occurring in the Potohar Plateau. This was confirmed further in May 14, 2012 when Shenzhen Bay Customs in China seized $25.4 \mathrm{~kg}$ scales of Indian pangolin from a passenger on a shuttle bus from Hong Kong to Shenzhen on the night of 13th May. Chinese passenger arrested confessed that he had obtained the pangolin scales when he worked in Pakistan and planned to sell them in China. In another incidence, on 1 November 2013, Beijing Customs reported that a total of $1030 \mathrm{~kg}$ scales of Indian pangolin equally to 1660 pangolins, have been seized. They also confirmed that after investigation that a criminal gang smuggled these scales from Pakistan. An average of 20 tonnes of pangolins and their parts have been trafficked internationally every year with smugglers using 27 new global trade routes annually (Traffic, 2017).The new comprehensive analysis of cross-border pangolin seizures has shown that a combined minimum of 120 tonnes of whole pangolins, parts and scales were confiscated by law enforcement agencies from 2010 to 2015. Another report released in the wake of the world's largest ever pangolin seizure, when China announced the seizure of 11.9 tonnes of scales from a ship in Shenzen in November 2017. These few reports highlight and establish the fact that Indian pangolins are under tremendous hunting pressure and they are illegally being hunted in Pakistan, and then are traded to China for the demand of their scales, which are used in Traditional Chinese Medicines.

Killing of the Indian Pangolin is also reported from many countries of the world, which include Sumatra, Indonesia (Sopyan, 2009), peninsular Malaysia (Chin and Pantel, 2009), and Potohar region of Pakistan (Mahmood et al., 2012). During eight years (from 2000 to 2007) about 30,000 pangolins were killed in Southeast Asia (Chin and Pantel, 2009). The killing of the pangolin is evident from many other studies like Mitra (1998), Mishra et al. (2004, 2011), Challender (2011), Mohanty (2011), Gubbi and Linkie (2012), Baillie et al. (2014), and Challender et al. (2014). In Pakistan it is believed by local ethnomedical practitioners (hakims) that the Indian Pangolin is a valuable source of traditional medicines (Roberts, 1997).

Results of the current study highlight that pangolins are still being illegally killed in Potohar Plateau (20132018) and also on adjoining Mirpur District of Azad Jammu and Kashmir. Our results confirm that 380 individuals of Indian pangolin have been illegally killed in the study area during the period from 2013 to 2018. Although local hunters have also been arrested and pangolins recovered from their possession, but meagre amount of penalty (Rs. $10,000 /-$ per pangolin) being charged and short duration of imprisonment ( 6 months) given to the culprits is not helping to saving the pangolins in the country. In return, these poachers are selling one pangolin for as much as Rs. $80,000 /-$ in the illegal market. But it is also encouraging that Punjab Wildlife and Parks Department have recovered 36 pangolins from the poachers which were released to their natural habitat in the study area. Earlier on, Akrim et al. (2017) had reported that Indian pangolin was being illegally killed in massive numbers in Kotli District of Azad Jammu \& Kashmir. The current study also reports the numberof local hunters involved in illegal hunting and killing of pangolins in the study area. Maximum number of hunters were recorded in Chakwal district followed by Attock and Rawalpindi districts. Coincidently maximum numbers of pangolin killings have also occurred in Chakwal and Attock districts during 2013-2018. These hunters trap pangolins both in summer and winter by using different techniques, and mostly they capture pangolins from the forest lands at night time and shift these to other localities from outside the villages. The pangolins in the study area were also illegally captured and killed during the study period by nomads (semi-settled people in the area), who sell them to some middle man who in turns transports these pangolins to large cities including Lahore, Rawalpindi and Karachi. These local hunters also follow the selling map of nomads. Earlier on Akrim et al. (2017) had reported that local hunters (90\%) were mainly involved in capturing and killing of Indian pangolin who sell them to nomads (first purchasers) who later on sold the scales to bigger parties involved in the illegal trade of pangolins. Hunters were followed by local farmers $8 \%$ and then laborers $1 \%$. This difference was significant that hunters killed more pangolin than other groups.

\section{ACKNOWLEDGEMENT}

The authors are highly thankful to the Inspector General Forest, Ministry of Climate Change, Govt. of Pakistan, Punjab Wildlife and Parks Department, Govt. of 
Punjab, Wildlife and Fisheries Department, Govt. of Azad Jammu and Kashmir, and their field staff, for facilitation and help during the current study. We are also grateful to Mr. Sajid Hussain, Mr. Abu Bakar, and Mr. Saeed U1 Islam for their contribution towards this work. We are also highly grateful to WWF Pakistan, Islamabad, for providing partial financial support for this study, through U.S. Fish and Wildlife Department Services, USA.

\section{Statement of conflict of interest}

The authors declare no conflict of interest.

\section{REFERENCES}

Akrim, F., Mahmood, T. Hussain, R., Qasim, S. and Zangi, I., 2017. Distribution pattern, population estimation and threats to the Indian Pangolin Manis crassicaudata (Mammalia: Pholidota: Manidae) in and around Pir Lasura National Park, Azad Jammu \& Kashmir, Pakistan. J. Threat. Taxa, 9: 99209927. https://doi.org/10.11609/jott.2914.9.3.99209927

Baillie, J., Challender, D.W.S., Kaspal, P., Khatiwada, A., Mohapatra, R. and Nash, H., 2014. Manis crassicaudata. The IUCN red list of threatened species. Version 2014.3. www.iucnredlist.org. Viewed on 7 October 2014.

Challender, D.W.S., Baillie, J., Ades, G., Kaspal, P., Chan, B., Khatiwada, A., Xu, I., Chin, S., Kc, R., Nash, H. and Hsieh, H., 2014. Manis pentadactyla. The IUCN red list of threatened species. Version 2014.3. www.iucnredlist. org. Viewed on 7 October 2014.

Challender, D.W.S., 2011. Asian pangolins: Increasing affluence driving hunting pressure. TRAFFIC Bull., 23: 92-93.

Challender, D.W.S., Harrop, S.R. and MacMillan, D.C., 2015. Understanding markets to conserve trade-threatened species in CITES. Biol. Conserv., 187: 249-259 https://doi.org/10.1016/j. biocon.2015.04.015

Chin, S.Y. and Pantel, S., 2009. Pangolin capture and trade in Malaysia. In Proceedings of the Workshop on Trade and Conservation of Pangolins Native to South and Southeast Asia, 30 June-2 July 2008, Singapore Zoo.

CITES, 2016. The status, trade and conservation of pangolins (Manis spp.). Seventeenth meeting of Conference of Parties, Johannesburg (South Africa), 24 September to $5^{\text {th }}$ October 2016.

Corbet, G. B, an Hill, J. E., 1992. Mammals of the Indo-Malayan region A systematic review. Oxford
University Press, Oxford. pp. 488.

Encyclopedia Britannica., 2016. Britannica $15^{\text {th }}$ Edition, Inc. Encyclopedia Britannica (Editor). Pp. 32640.

GACC (General administration of custom, People Republic of China), 2012. Http://www.customs. gov.cn/publish/portal0/tab39267/inf365276.htm [accessed 20 March 2017]. [In Chinese].

Gaubert, P. and Antunes, A., 2005. Assessing the taxonomic status of the Palawan pangolin Manis culionensis (Pholidota) using discretemorphological characters. J. Mammal., 86: 1068-1074. https://doi. org/10.1644/1545-1542(2005)86[1068:ATTSOT]2 $0 . \mathrm{CO} ; 2$

Gubbi, S. and Linkie, M., 2012. Wildlife hunting patterns, techniques, and profile of hunters in and around Periyar tiger reserve. J. Bombay nat. Hist. Soc., 109: 165-172.

IUCN., 2014. IUCN red list of threatened species. version available at: www.redlist.org.

IUCN., 2018. IUCN red list of threatened species. version available at: www.redlist.org.

Mahmood, T., Hussain, R., Irshad, N., Akrim, F. and Sajid, M.N., 2012. Illegal mass killing of Indian pangolin (Manis crassicaudata) in Potohar Region, Pakistan. Pakistan J. Zool., 44: 1457-1461.

Mahmood, T., Hussain, R., Irshad, N., Akrim, F. and Sajid, M.N., 2017. Distribution and illegal killing of the Endangered Indian pangolin Manis crassicaudata on the Potohar Plateau, Pakistan. Oryx, 53: 159-164 https://doi.org/10.1017/ S0030605317000023

Mishra, C., Datta, A. and Madhusudan, M.D., 2004. The high-altitude wildlife of western arunachal pradesh: a survey report. CERC Technical Report No. 8. Nature Conservation Foundation, International Snow Leopard Trust, and Wildlife Conservation Society (India Program), Mysore, India.

Mishra, N., Rout, S.D. and Panda, T., 2011. Ethnozoological studies and medicinal values of Similipal Biosphere Reserve, Orissa. India. Afri. J. Pharm. Pharmacol., 5: 6-11.

Mitra, S., 1998. On the scales of scaly anteater Manis crassicaudata. J. Bombay nat. Hist. Soc., 95: 495498.

Mohanty, B., 2011. Wildlife poaching in Orissa. PhD (Life Science) thesis, submitted to North Orissa University, Baripada, Odisha.

Munawar, N., Hussain, I. and Mahmood, T., 2018. Occurrence of rodent species in agricultural lands during cropping and non-cropping seasons of Pothwar Plateau, Pakistan. Pakistan J. Zool., 50: 
1663-1669.

Newton, P., Nguyen, V.T., Roberton, S. and Bell, D., 2008. Pangolins in peril: Using local hunter's knowledge to conserve elusive species in Vietnam. Endang. Sp. Res., 6: 41-53. https://doi.org/10.3354/ esr006041

Roberts, T.J., 1997. The mammals of Pakistan. Benn, London.UK. pp. 361.

Sopyan, E., 2009. Malayan pangolin Manis javanica trade in Sumatra, Indonesia. In: Proceedings of the Workshop on Trade and Conservation of Pangolins Native to South and Southeast Asia (eds. S. Pantel and S.Y. Chin), 30 June-2 July 2008, Singapore Zoo, Singapore.
Traffic., 2017. A report on "In the wake of world's largest ever pangolin scale seizure, new analysis exposes plethora of pangolin trafficking routes". Published 15th December 2017. Available at: https://www.traffic.org/publications/reports/theglobal-trafficking-of-pangolins/.

Wu, S.B, Lui, N., Zhang, Y. and Ma, G., 2004. Assessment of threatened status of Chinese pangolin (Manis pentadactyla). Chinese J. appl. environ. Biol., 10: 456-461.

$\mathrm{Wu}$, S.B. and Ma, G., 2007. The status and conservation of pangolins in China. TRAFFIC East Asia Newsl., 4: $1-5$. 